\section{Pascal's Arithmometer}

AT a well-attended meeting of the Newcomen Society held in the rooms of the Royal Society on February 16, Mr. R. Nilsson gave a paper entitled "The Pascal Arithmometer and Other Means to Solve Mathematical Problems". The audience included many distinguished foreigners. Premising that accuracy in calculation is one of the most important elements in scientific progress, Mr. Nilsson said that by a calculating machine is understood a great number of working parts conjoined in action by various mechanisms to obtain arithmetical or algebraic results. Describing in detail, with the use of slides, the arithmometer invented by Blaise Pascal (1623-62) when a youth of nineteen, the author said that Pascal's basic invention was the 'ten-carry-over' which is seen in the counters, meters, cash registers, etc., which are part and parcel of our daily life. Two years were occupied in making the first machine, and more than fifty models were constructed before the machine was in working order. Pascal showed it in 1647 to Descartes and in 1649 to Chancellor Séguier, who helped him to obtain a patent. Mr. Nilsson mentioned the machines which succeeded Pascal's; Sir Samuel Morland's (1666), that of Leibniz (1672), and those of Grillet, Poleni and Charles Xavier Thomas, of Colmar, Alsace, who began the manufacture of calculating machines. In the ante-room was a representative exhibition of machines and docu. ments. In proposing a vote of thanks to the Royal Society for its hospitality, the chairman, Eng. Captain E. C. Smith, said that there could be no more suitable place for the gathering. Pascal was associated with some of the French men of science whose meetings led to the founding of the French Academy of Sciences, and his death coincided with the grant of the Act of Incorporation to the Royal Society.

\section{Ankara University : Opening of Faculty of Science}

A NEW Faculty of Science in the University of Ankara was opened on November 8, 1943, in the presence of President Inönü. The President, accompanied by the Prime Minister, Sükrü Saracoglu, was welcomed at the inauguration ceremony by the chairman of the National Assembly, B. B. Abdülhalik Renda. All the members of the Cabinet were present Mr. R. F. Lucas, of the British Council, was also invited to attend the ceremony. The Minister of Education, Hasan Ali Yücel, in his opening address, referred to Turkish progress during the twenty years since the establishment of the Republic. The consequent changes in the national outlook have developed a need for scientific and technical training which is now enhanced by the mechanization of armed forces in a world at war. Hitherto Turkish educational institutions have lacked equipment for practical training; but Turkey has now an established policy of education based on positive knowledge to reinforce the earlier practice of theoretical training only. The nation needs mechanical engineers, mining and civil engineers, and the great problem of Turkey to-day is to find the means for training students in large enough numbers to satisfy the national requirements without reducing the educational standard. The Government is keenly aware of these needs and has sanctioned the establishment of this faculty as a step to meet them. The assembly was later addressed by the Rector of the Faculty, by a student, and by Prof. Kerim Erin, of the Faculty of Science, University of Istanbul.
The new Faculty is temporarily installed in the Gazi Teachers' Training Institute. The Dean of the Faculty, Bay Hayri Dener, is also professor of physics, and a member of the Board of Education. The chair of chemistry and the presidency of the new Chemistry Institute of the Faculty is held by Dr. Avni Refik Bekman. The Ministry of Education has invited the British Council to nominate British candidates for a professorship in each of the existing Departments of Chemistry, Physics and Mathematics. The establishment of this Faculty thus implements the approval of the Bill recently presented by the Turkish Cabinet to the Chamber of Deputies.

\section{Science in China}

A Pamphlet entitled "The Place of Science in China" by Yap Pow-Meng, honorary secretary of the National Science Society of China, British Branch, published by the China Campaign Committee, 34 Victoria Street; London, S.W.I (6d.), attributes the failure of the scientific method to establish itself in the intellectual tradition of China mainly to social and economic reasons. From the first, the makers of the revolution of 1911 seized upon science as a means of achieving their ideal of a progressive, industrialized China, and the pamphlet gives a brief account of the organization of education in science, of scientific research institutions, including the Academia Sinica, which is essentially an organization providing facilities for scientific research, the National Academy of Peiping, the Science Society of China, the National Science Society of China, the Fan Memorial Institute of Biology, the Henry Lester Institute for Medical Research, and private technical research institutions, of which the most important is the Hangwai Institute of Industrial Chemistry.

The majority of the research institutions of China were founded in the coastal areas and have now been moved to the west and south-west. Apart from those of the Radium Institute of the Peiping Academy and the Metals Research Institute and Science School of the National Tsing-hua University, Chinese researches in physics and chemistry have not so far been impressive, and in China as elsewhere experimental psychology has not made a complete break from the old philosophical psychology. The pamphlet also includes some account of the organization of science in China's war effort under the National Economic Council, the Ministry of Economic Affairs, the National Resources Commission, the Ministry of Agriculture and Forestry, the National Geological Survey and the National Health Administration, as well of the attempts being made to overcome educational difficulties due to the War.

\section{Isinglass as a Substitute for Human Blood Plasma}

MaNY substances have been tried as substitutes for human blood plasma. Recently (NATURE, 153, 145 ; 1944) reference was made to the use of 'despeciated bovine serum'. A recent note (Edin. Med. J., 50,$758 ; 1943$ ) describes the use of isinglass, which is available in sufficient quantities and can be cheaply prepared, as a substitute for human blood plasma. Its injection causes no antigenic response. Prof. N. B. Taylor and Miss M. S. Moorhouse (Canad. Med. Assoc. J., 49, $251 ; 1943)$ transfused 25 dogs from which 47-71 per cent of the blood had been bled, with 4 or 6 per cent solutions of isinglass, and most of the dogs made a complete and uneventful recovery. Repeated injections over a period of weeks caused 